\title{
FAKTOR-FAKTOR YANG MEMPENGARUHI PENGGUNAAN FASILITAS E-FILLING DALAM PENYAMPAIAN SPT MASA OLEH WAJIB PAJAK DI KOTA BENGKULU
}

\author{
Hesti setiorini $^{1}$ \\ E-mail : hestisetiorini@umb.ac.id \\ Yusmaniarti $^{2}$ \\ E-mail : yusmaniarti@umb.ac.id
}

UNIVERSITAS MUHAMMADIYAH BENGKULU

\begin{abstract}
The title of this study is the factors that influence the use of e-filling tax facilities by taxpayers as a means of submitting effectively and efficiently annual notice (SPT) in Pratama tax service office of Bengkulu city. In the use of e-filling facilities, not all taxpayers use it for various reasons. This study aims to find out the empirical evidence of the influence of perception of usefulness (X1), perception of easiness (X2), complexity $(X 3)$, security and confidentiality (X4), taxpayer information technology readiness (X5), and counseling to taxpayers (X6) toward the intensity of behavior in the use of e-filling (y) in the Pratama tax service office of Bengkulu city. In this study, the samples taken were 100 taxpayers registered in the Pratama tax service office of Bengkulu City. Data collection is done through direct observation and surveys, and the data were obtained by distributing questionnaires to the respondents. This study uses Technology Acceptance Models (TAM) with the SPSS program. The results showed that the perception of usefulness (X1) had a significant positive influence on the intensity of behavior for the use of e-filling. Easiness perception (X2) had a positive significant influence on the intensity of behavior for the use of e-filling, Complexity (X3) had significant negative influence on the intensity of behavior for e-filling, security and confidentiality (X4) had significant positive influence on the intensity of behavior for filling the e-filling, taxpayer information technology readiness (X5) had a significant positive influence on the intensity of behavior for filling the e-filling, and counseling to taxpayers (X6) had a significant positive influence on the intensity of behavior for filling the e-filling.
\end{abstract}

Keywords: Perception of Usability, Perception of Convenience, Complexity, Security and Confidentiality, Taxpayer Information Technology Readiness and counseling to Taxpayers on Behavioral Intensity in the Use of E-Filling.

\section{PENDAHULUAN}

Selama ini kualitas pelayanan publik masih dalam kondisi memperihatinkan, hal ini $E$ Filling adalah suatu cara penyampaian Surat Pemberitahuan (SPT) secara elektronik yang dilakukan secara online dan real time melalui internet pada website Direktorat Jenderal Pajak. Bagi wajib pajak yang hendak menyampaikan laporan SPT Tahunan $\mathrm{PPh}$ Orang Pribadi secara langsung pada aplikasi e-filling di DJP Online 
(www.pajak.go.id). Digitalisasi administrasi perpajakan dimulai di tahun 2004 yang ditandai dengan dikeluarkannya Keputusan Direktur Jenderal Pajak Nomor KEP88/PJ/2004 tanggal 14 Mei 2004 tentangpenyampaian SPT secara elektronik. Setelah sukses dengan program e-SPT pada tanggal 24Januari 2005, Presiden Republik Indonesia bersama dengan DJP meluncurkan produk e-filling atau Electronic Filing System. Melalui e-filling Wajib Pajak dapat melakukan penyampaian atau pelaporan pajak dengan SPT secara online.

Kemudian dikeluarkan PER-36/PJ/2013 tentang Perubahan Atas Peraturan DJP Nomor PER-47/PJ/2008 tentang tata cara Penyampaian Surat Pemberitahuan dan Penyampaian Pemberitahuan Perpanjangan Surat Pemberitahuan Tahunan secara Elektronik (e-filling) melalui Perusahaan Penyedia Jasa Aplikasi (ASP). Selanjutnya dikeluarkan PER03/PJ/2015 tentang penyampaian pemberitahuan elektronik untuk melengkapi peraturan sebelumnya Aplikasi tersebut mempermudah Wajib Pajak dalam pelaporan SPT. Wajib Pajak yang semula melaporkan SPT langsung ke Kantor Pelayanan Pajak (KPP) dalam bentuk kertas atau formulir, sekarang pelaporan SPT dapat dilakukan secara online dimana saja dan kapan saja.

Sistem e-filling di Bengkulu membuat Wajib Pajak tidak perlu lagi menghabiskan waktunya untuk datang, mengantri di Kantor Pelayanan Pajak (KPP) untuk menyampaikan suatu SPT karena sekarang semua itu dapat dilakukan secara online kapan saja dan di mana saja. Selain itu, penggunaan efiling dapat mengurangi beban proses administrasi laporan pajak menggunakan kertas. Saat ini belum semua WP menggunakan e-filling karena berbagai alasan.

Kurangnya sosialisasi dari DJP, WP belum terbiasa mengaplikasikan sebuah teknologi baru, Pola pikir yang menganggap penggunaan sistem komputer dalam pelaporan SPT akan lebih menyulitkan,padahal sebenarnya pelaporan SPT secara komputerisasi jauh lebih mudah dan memiliki manfaat yang besar bagi WP maupun DJP.

Dengan adanya system e-filling, diharapkan memberikan kemudahan kepada wajib pajak dalam menyelesaikan segala kewajiban yang berkaitan dengan pajak penghasilan atas pendapatan yang diperolehnya dalam periode tahun pajak. Salah satu sasaran yang dilakukan Dirjen Pajak adalah perbaikan kinerja yang kelak dapat meningkatkan penerimaan pajak maupun pelayanan yang efektif kepada wajib pajak dalam penyampaian SPT nya.pada kenyataannya system e-filling banyak mengalami hambatan dan kurang diminati oleh wajib pajak karena berbagai alasan. Penelitian ini bisa menjadi bahan masukan terhadap direktorat jendral pajak terkait dengan pengembangan $e$-filling kedepannya.

Pajak merupakan pendapatan negara yang paling besar. Penerimaan pajak berasal dari iuran yangharus dibayar oleh rakyat sebagai konsekuensi berlakunya Undang-Undang. Wajib Pajak tidak mendapat imbalan langsung dari iuran yang dibayarkan. Sehingga Wajib Pajak enggan untuk membayar pajak. Padahal pajak bertujuan meningkatkan kesejahteraan masyarakat dalam bentuk peningkatan maupun perbaikan sarana publik. Menyikapi hal tersebut, maka DJP perlu meningkatkan kualitas pelayanan bagi Wajib 
Pajakuntuk pelaporan Surat Pemberitahuan (SPT) baik SPT Masa maupun SPT Tahunan.

Melaporkan Surat Pemberitahuan (SPT) merupakan salah satu kewajiban para Wajib Pajak sebagaimana amanat Undang-undang Perpajakan Indonesia. Undang-undang No. 28 Tahun 2007 dalam pasal (3) menyebutkan:

"Setiap Wajib Pajak wajib mengisi Surat Pemberitahuan dengan benar, lengkap, dan jelas dalam bahasa Indonesia dengan menggunakan huruf latin, angka Arab, satuan mata uang Rupiah, dan menandatangani serta menyampaikannya ke Kantor Direktorat Jenderal Pajak tempat Wajib Pajak terdaftar atau dikukuhkan atau tempat lain yang ditetapkan oleh direktur jenderal pajak". Saat ini belum semua WP menggunakan $e$ filling karena berbagai alasan.

Kurangnya sosialisasi dari DJP, WP belum terbiasa mengaplikasikan sebuah teknologi baru, Pola pikir yang menganggap penggunaan sistem komputer dalam pelaporan SPT akan lebih menyulitkan, padahal sebenarnya pelaporan SPT secara komputerisasi jauh lebih mudah dan memiliki manfaat yang besar bagi WP maupun DJP khuusnya pada WP di kota Bengkulu yang akan menjadi objek penelitian.

Permasalahan yang diteliti adalah faktor-faktor yang mempengaruhi penggunaan fasilitas $e$-filling oleh wajib pajak sebagai sarana penyampaian spt masa pada kantor pelayanan pajak pratama kota bengkulu. Tujuan Penelitian ini untuk mengetahui FaktorFaktor Yang Mempengaruhi Penggunaan Fasilitas E-Filling Oleh Wajib Pajak Sebagai Sarana Penyampaian SPT Masa Secara Efektif Dan Efisien Pada Kantor Pelayanan Pajak Pratama Kota Bengkulu.

\section{METODE PENELITIAN}

Penelitian ini merupakan penelitian deskriftif, Jenis penelitian ini adalah kuantitatif. Penelitian dilakukan di Kantor Pelayanan Pajak Pratama Kota Bengkulu. Populasi dalam penelitian ini adalah seluruh wajib pajak tahun yang terdaftar di Kantor Pelayanan Pajak Pratama Kota Bengkulu sebanyak 21.061 orang. sampel dalam penelitian ini adalah sebanyak 100 responden. Metode pengambilan sampel dalam penelitian ini adalah convenience sampling.

\section{HASIL PENELITIAN DAN PEMBAHASAN Uji Validitas}

Teknik yang digunakan untuk melakukan uji validitas adalah dengan menggunakan Metode Pearson Corrélation. Kriteria yang ditetapkan dalam menentukan validitas adalah $r$ hitung (koefisien korelasi) lebih besar dari batasan $r$ table sebesar 0,361 pada taraf signifikan 0,05. Jadi, jika koefisien korelasinya lebih besar dari nilai $r$ tabel maka instrument pengukur dapat dikatakan valid (Priyatno, $2010: 21$ ) 
Tabel 1. Uji Validitas Instrimen

\begin{tabular}{|c|c|c|c|c|}
\hline Variabel & Item & $\begin{array}{c}\text { Pearson } \\
\text { Correlation }\end{array}$ & $\mathrm{r}$ tabel & keterangan \\
\hline Validitas & 1 & 0,777 & 0,361 & Valid \\
\hline Persepsi & 2 & 0,785 & 0,361 & Valid \\
\hline Kegunaan & 3 & 0,760 & 0,361 & Valid \\
\hline (X1) & 4 & 0,644 & 0,361 & Valid \\
\hline Validitas & 1 & 0,719 & 0,361 & Valid \\
\hline Persepsi & 2 & 0,715 & 0,361 & Valid \\
\hline \multirow{4}{*}{$\begin{array}{l}\text { Kemudahan } \\
\text { (X2) }\end{array}$} & 3 & 0,781 & 0,361 & Valid \\
\hline & 4 & 0,723 & 0,361 & Valid \\
\hline & 5 & 0,685 & 0,361 & Valid \\
\hline & 6 & 0,704 & 0,361 & Valid \\
\hline Validitas & 1 & 0,724 & 0,361 & Valid \\
\hline \multirow{2}{*}{$\begin{array}{c}\text { Kerumitan } \\
(\mathrm{X} 3)\end{array}$} & 2 & 0,768 & 0,361 & Valid \\
\hline & 3 & 0,691 & 0,361 & Valid \\
\hline Validitas & 1 & 0,571 & 0,361 & Valid \\
\hline \multirow{2}{*}{$\begin{array}{c}\text { Keamanan } \\
\text { dan }\end{array}$} & 2 & 0,617 & 0,361 & Valid \\
\hline & 3 & 0,662 & 0,361 & Valid \\
\hline \multirow{2}{*}{$\begin{array}{c}\text { Kerahasiaan } \\
\text { (X4) }\end{array}$} & 4 & 0,646 & 0,361 & Valid \\
\hline & 5 & 0,695 & 0,361 & Valid \\
\hline \multirow{4}{*}{$\begin{array}{c}\text { Validitas } \\
\text { Kesiapan } \\
\text { Teknologi } \\
\text { Informasi } \\
\text { WP (X5) }\end{array}$} & 1 & 0,718 & 0,361 & Valid \\
\hline & 2 & 0,792 & 0,361 & Valid \\
\hline & 3 & 0,785 & 0,361 & Valid \\
\hline & & & & \\
\hline \multirow{3}{*}{$\begin{array}{c}\text { Validitas } \\
\text { Penyuluhan } \\
\text { Kepada WP } \\
\text { (X6) }\end{array}$} & 1 & 0,772 & 0,361 & Valid \\
\hline & 2 & 0,791 & 0,361 & Valid \\
\hline & & & & \\
\hline \multirow{2}{*}{$\begin{array}{l}\text { Validitas } \\
\text { Intensitas }\end{array}$} & 1 & 0,752 & 0,361 & Valid \\
\hline & 2 & 0796 & 0361 & Volid \\
\hline $\begin{array}{c}\text { Perilaku } \\
\text { dalam }\end{array}$ & 2 & 0,190 & & valu \\
\hline \multicolumn{5}{|l|}{ Penggunaan } \\
\hline E-Filling (Y) & & & & \\
\hline
\end{tabular}

\section{Uji Reliabilitas}

Uji reliabilitas pada penelitian ini menggunakan teknik Formula Alpa Croanbach. Untuk menginterprestasikan tinggi rendahnya reliabilitas instrument sebagai pedoman didasarkan pada ketentuan yang telah dijelaskan sebelumnya. 
Tabel 2 Hasil Uji Reliabilitas

\begin{tabular}{ccc}
\hline Variabel & Croanbach's & Keterangan \\
\hline Persepsi Kegunaan & 0,793 & Reliabel \\
(X1) & & \\
Persepsi Kemudahan & 0,780 & Reliabel \\
(X2) & & \\
Kerumitan (X3) & 0,790 & Reliabel \\
Keamanan dan & 0,753 & Reliabel \\
Kerahasiaan (X4) & & \\
Kesiapan Teknologi & 0,810 & Reliabel \\
Informasi Wajib Pajak & & \\
$\quad$ X5) & & \\
$\begin{array}{c}\text { Penyuluhan Kepada } \\
\text { WP (X6) }\end{array}$ & 0,818 & Reliabel \\
$\begin{array}{c}\text { Intensitas Perilaku } \\
\text { dalam Penggunaan E- }\end{array}$ & 0,812 & Reliabel \\
Filling & & \\
\hline
\end{tabular}

\section{Uji Asumsi Klasik}

Uji normalitas merupakan salah satu bagian dari uji persyaratan analisis data atau uji asumsi klasik. Dasar dalam pengambilan keputusan dalam uji normalitas data Kolmogorov-Smirnov yakni jika nilai signifikansi lebih besar dari 0,005 maka data tersebut berdistribusi normal.

Tabel 3 One-Sample Kolmogorov-Smirnov Test

\begin{tabular}{|c|c|c|}
\hline & & Unstandardized Residual \\
\hline \multicolumn{2}{|l|}{$\bar{N}$} & 100 \\
\hline Normal & Mean & .0000000 \\
\hline Parametersa & $\begin{array}{c}\text { Std. } \\
\text { Deviation }\end{array}$ & .45744524 \\
\hline \multirow{3}{*}{$\begin{array}{l}\text { Most Extreme } \\
\text { Differences }\end{array}$} & Absolute & .059 \\
\hline & Positive & .044 \\
\hline & Negative & -.059 \\
\hline \multicolumn{2}{|c|}{ Kolmogorov-Smirnov Z } & .587 \\
\hline \multicolumn{2}{|c|}{ Asymp. Sig. (2-tailed) } & .881 \\
\hline
\end{tabular}

. Test distribution is Normal.

Berdasarkan tabel 3 diketahui bahwa nilai signifikansi sebesar 0,881 lebih besar dari 0,005, sehingga dapat disimpulkan bahwa data yang diuji dalam penelitian ini berdistribusi normal.

\section{Uji Normalitas Data}

Uji normalitas bertujuan untuk menguji apakah dalam model regresi, variabel dependen dan independen keduanya mempunyai distribusi normal atau tidak. Dalam penelitian uji normalitas yang digunakan adalah grafik histogram dan kurva penyebaran P-Plot 


\section{Gambar 1}

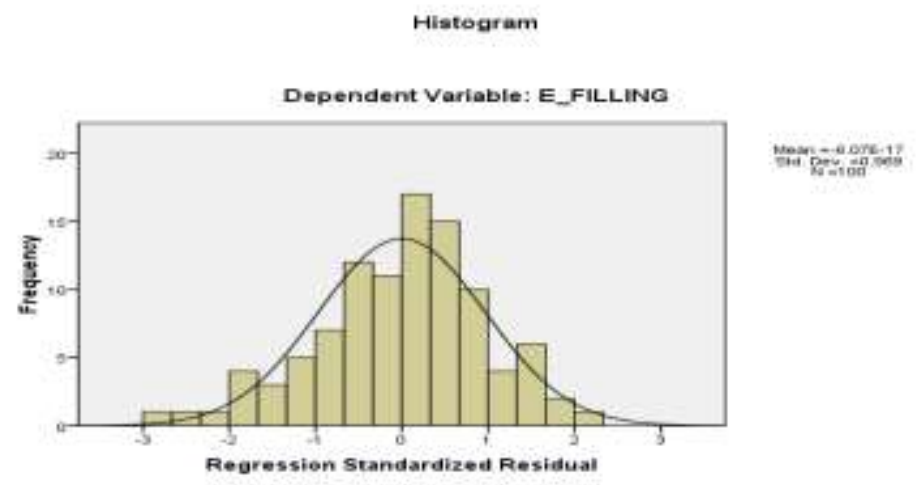

Dengan melihat grafik histogram, dapat disimpulkan bahwa grafik histogram menunjukkan bahwa grafik histogram memberikan pola distribusi yang mendekati normal, hal ini dibuktikan dengan melihat bahwa grafik membentuk simetris dan mengikuti garis diagonal. Metode yang lebih akurat untuk melihat apakah data terdistribusi normal adalah normal probability plot.

\section{Gambar 2}

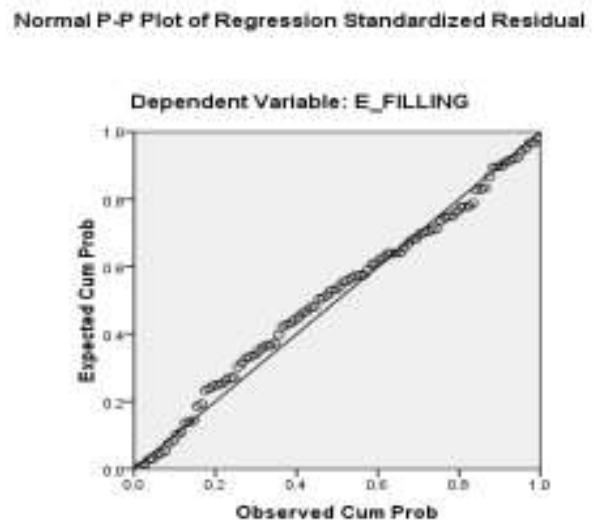

Dengan melihat grafik normal plot, kita dapat melihat bahwa titik menyebar disekitar garis diagonal dan penyebarannya mengikuti garis diagonal, sehingga dapat dikatakan bahwa pola distribusinya normal. Dengan melihat kedua grafik diatas, dapat disimpulkan bahwa model regresi dalam penelitian ini dapat digunakan karena memenuhi asumsi normalitas.

\section{Analisis Data}

\section{Uji Regresi Berganda}

Uji regresi linear berganda untuk mengetahui ada tidaknya pengaruh variabel independen terhadap variabel dependen. Besarnya pengaruh variabel independen terhadap variabel dependen secara bersama-sama dapat dihitung melalui suatu persamaan regresi berganda. Tabel 4 menunjukan hasil analisis mengenai koefisien model regresi 
Tabel 4. Koefisien Regresi

\begin{tabular}{|c|c|c|c|c|c|c|}
\hline \multicolumn{7}{|c|}{ Coefficientsa } \\
\hline & \multirow[t]{2}{*}{ Model } & \multicolumn{2}{|c|}{$\begin{array}{l}\text { Unstandardized } \\
\text { Coefficients }\end{array}$} & \multirow{2}{*}{$\begin{array}{c}\text { Standardized } \\
\text { Coefficients } \\
\text { Beta }\end{array}$} & \multirow[b]{2}{*}{$\mathrm{T}$} & \multirow[b]{2}{*}{ Sig. } \\
\hline & & B & Std. Error & & & \\
\hline \multirow[t]{7}{*}{1} & (Constant) & .547 & .767 & & .714 & .477 \\
\hline & Kegunaan & .173 & .042 & .395 & 4.138 & .000 \\
\hline & Kemudahan & .086 & .026 & .294 & 3.274 & .001 \\
\hline & Kerumitan & .020 & .031 & .041 & .642 & .522 \\
\hline & Keamanan & .029 & .025 & .068 & 1.162 & .248 \\
\hline & Tekhnologi & .040 & .017 & .144 & 2.357 & .021 \\
\hline & Penyuluhan & .177 & .059 & .212 & 2.995 & .004 \\
\hline & ependent Vari & bel : & FILLING & & & \\
\hline
\end{tabular}

Persamaan Regresi dapat dijelaskan dalam model berikut:

$\mathbf{Y}=\mathbf{a}+\mathrm{b} 1 \times 1+b 2 \times 2+b 3 \times 3+b 4 \times 4+b 5 \times 5+b 6 \times 6$

$\mathrm{Y}=0,547+0,173 \times 1+0,086 \times 2+0,020 \times 3+$

$0,029 \times 4+0,040 \times 5+0,177 \times 6$

Dalam persamaan model regresi diketahui nilai koefisien konstanta adalah sebesar 0,547 hal ini berarti jika tidak ada perubahan variabel persepsi kegunaan (X1), persepsi kemudahan (X2) kerumitan (X3), keamanan dan kerahasiaan (X4), kesiapan tekhnologi informasi wajib pajak (X5) dan penyuluhan kepada wajib pajak (X6) yang mempengaruhi, maka intensitas perilaku dalam penggunaan e filing sebesar 0,547.

Hasil uji regresi berganda untuk variabel independen dapat diketahui bahwa Nilai koefisien persepsi kegunaan (X1) sebesar 0,173 berpengaruh positif terhadap intensitas perilaku dalam penggunaan e filling (Y). Hal ini mengandung arti bahwa setiap kenaikan persepsi kegunaan sebesar satu satuan maka variabel intensitas perilaku dalam penggunaan e filling naik sebesar 0,173 dengan asumsi bahwa variabel lainnya masih tetap konstan. Nilai koefisien persepsi kemudahan (X2) sebesar 0,086 berpengaruh positif terhadap intensitas perilaku dalam penggunaan e filling(Y). Hal ini mengandung arti bahwa setiap terjadi kenaikan persepsi kemudahan sebesar satu satuan maka variabel intensitas perilaku dalam penggunaan efilling naik sebesar 0,086 dengan asumsi bahwa variabel lainnya masih tetap konstan.

Nilai koefisien kerumitan (X3) sebesar 0,020 tidak berpengaruh terhadap intensitas perilaku dalam penggunaan e filling (Y). Nilai koefisien keamanan dan kerahasiaan (X4) sebesar 0,029 tidak berpengaruh terhadap intensitas perilaku dalam penggunaan e filling(Y). Nilai koefisien kesiapan tekhnologi informasi wajib pajak (X5) sebesar 0,040 berpengaruh positif terhadap intensitas perilaku dalam penggunaan e filling(Y). Hal ini mengandung arti bahwa setiap terjadi kenaikan kesiapan tekhnologi informasi wajib pajak sebesar satu satuan maka variabel intensitas perilaku dalam penggunaan e fillingnaik sebesar 0,040 dengan asumsi bahwa variabel lainnya masih tetap konstan. 
Nilai koefisien penyuluhan kepada wajib pajak (X6) sebesar 0,177 berpengaruh positif terhadap intensitas perilaku dalam penggunaan e-filling(Y). Hal ini mengandung arti bahwa setiap terjadi kenaikan penyuluhan kepada wajib pajak sebesar satu satuan maka variabel intensitas perilaku dalam penggunaan e fillingnaik sebesar 0,177dengan asumsi bahwa variabel lainnya masih tetap konstan.

\section{Hasil Uji Koefisien Determinasi}

Analisis koefisien determinasi dilakukan untuk melihat seberapa besar persentase pengaruh variabelpersepsi kegunaan, persepsi kemudahan, kerumitan, keamanaan dan kerahasiaan, kesiapan tekhnologi informasi wajib pajak, penyuluhan kepada wajib pajak terhadap intensitas perilaku dalam penggunaan e filling. Tabel dibawah ini merupakan hasil analisis uji koefisien determinasi:

\section{Tabel 5 Uji Koefisien Determinasi}

\begin{tabular}{ccccc} 
& \multicolumn{3}{c}{ Model Summaryb } \\
\hline & \multicolumn{3}{c}{$\mathrm{R} \quad$ Adjusted } \\
Model & $\mathrm{R}$ & Square R Square td. Error of the Estimate \\
\hline 1 & $.830 \mathrm{a}$ & .690 & .670 & 172 \\
\hline
\end{tabular}

a. Predictors: (Constant), Penyuluhan, Kerumitan, Keamanan, Tekhnologi, Kemudahan, Kegunaan

b. Dependent Variabel : E_FILLING

Tabel 5 diatas menunjukkan bahwa nilai adjusted $\mathrm{R}$ Square yang diperoleh sebesar 0,670 yang menunjukkan bahwa intensitas perilaku dalam penggunaan e fillingyang ada di Kantor Pelayanan Pajak Pratama Bengkulu dipengaruhi oleh variabel persepsi kegunaan, persepsi kemudahan, kerumitan, keamanaan dan kerahasiaan, kesiapan tekhnologi informasi wajib pajak, penyuluhan kepada wajib pajak $67 \%$ dan sisanya $33 \%$ dipengaruhi oleh variabel lain yang belum diteliti dan tidak termasuk dalam analisis regresi ini.

\section{Uji Statistik F}

Pengujian ini dilakukan untuk menguji apakah terdapat pengaruh yang signifikan antara persepsi kegunaan, persepsi kemudahan, kerumitan, keamanaan dan kerahasiaan, kesiapan tekhnologi informasi wajib pajak, penyuluhan kepada wajib pajak terhadap intensitas perilaku dalam penggunaan e fillingsecara bersama-sama.

\section{Tabel 6 Uji Statistik F}

INOVAb

\begin{tabular}{|c|c|c|c|c|c|}
\hline Todel & $\begin{array}{l}\text { um } \\
\text { quares }\end{array}$ & $\mathrm{C}_{\mathrm{f}}$ & $\begin{array}{l}\text { Mean } \\
\text { quare }\end{array}$ & & ig. \\
\hline 'egression & 6.034 & & .672 & 4.442 & $300 a$ \\
\hline 'esidual & 0.716 & 3 & 223 & & \\
\hline otal & 6.750 & 9 & & & \\
\hline
\end{tabular}

- Predictors: (Constant), Penyuluhan, Kerumitar seamanan, Tekhnologi, Kemudahan, Kegunaan

b. Dependent Variabel : E_FILLING 
Dari hasil perhitungan dengan tingkat keyakinan sebesar 95\% atau $\alpha=0,05$ diperoleh nilai F tabel sebesar 2,20 sedangkan nilai F hitung sebesar 34.442.

Hal tersebut menunjukkan bahwa nilai $\mathrm{F}$ hitung > nilai $\mathrm{F}$ tabel $(34.442>2,20)$ dengan tingkat signifikansi 0,000 lebih kecil dari 0,005. Maka Ha diterima. Secara simultan variabel persepsi kegunaan, persepsi kemudahan, kerumitan, keamanaan dan kerahasiaan, kesiapan tekhnologi informasi wajib pajak, penyuluhan kepada wajib pajak berpengaruh signifikan terhadap intensitas perilaku dalam penggunaan $\mathrm{e}$ filling.Sehingga jika persepsi kegunaan, persepsi kemudahan, kerumitan, keamanaan dan kerahasiaan, kesiapan tekhnologi informasi wajib pajak, penyuluhan kepada wajib pajak secara bersama-sama meningkat, maka intensitas perilaku dalam penggunaan e filling juga meningkat.

\section{Uji Statistik t}

Pengujian secara parsial (uji t) dilakukan untuk menentukan apakah variabel persepsi kegunaan, persepsi kemudahan, kerumitan, keamanaan dan kerahasiaan, kesiapan tekhnologi informasi wajib pajak, penyuluhan kepada wajib pajakterhadap intensitas perilku dalam penggunaan e filling secara parsial.

Tabel 8 Hasil Uji Statistik $t$

Coefficientsa

\begin{tabular}{ccccccc}
\hline \multirow{2}{*}{ Model } & \multicolumn{2}{c}{$\begin{array}{c}\text { Unstandardized } \\
\text { Coefficients }\end{array}$} & $\begin{array}{c}\text { Standardized } \\
\text { Coefficients }\end{array}$ & & \\
\cline { 3 - 5 } & & $\mathrm{B}$ & Std. Error & Beta & $\mathrm{t}$ & Sig. \\
\hline 1 & (Constant) & .547 & .767 & & .714 & .477 \\
& Kegunaan & .173 & .042 & .395 & 4.138 & .000 \\
Kemudahan & .086 & .026 & .294 & 3.274 & .001 \\
& Kerumitan & .020 & .031 & .041 & .642 & .522 \\
& Keamanan & .029 & .025 & .068 & 1.162 & .248 \\
& Tekhnologi & .040 & .017 & .144 & 2.357 & .021 \\
& Penyuluhan & .177 & .059 & .212 & 2.995 & .004 \\
\hline
\end{tabular}

. Dependent Variabel : E_FILLINC

Dari tabel diatas menunjukkan hasil uji t adalah bahwa Nilai t hitung variabel persepsi kegunaan (X1) adalah sebesar 4,138 yang lebih besar apabila dibandingkan dengan nilai $\mathrm{t}$ table sebesar 1,985 degree of freedom sebesar 93 ( $\mathrm{t}$ hitung $>\mathrm{t}$ table), tingkat signifikansi 0,05/2 (uji 2 sisi), dengan tingkat signifikasi sebesar 0,000 lebih kecil dari nilai alpha $0,05(0,000<0,05)$. Dapat disimpulkan bahwa untuk hipotesis $1 \mathrm{Ha}$ diterima dan Ho ditolak yang berarti bahwa persepsi kegunaan berpengaruh positif dan signifikan terhadap intensitas perilaku dalam penggunaan e filling.

Nilai t hitung variabel persepsi kemudahan (X2) adalah sebesar 3,274 yang lebih besar apabila dibandingkan dengan nilai $\mathrm{t}$ table sebesar 1,985 degree of freedom sebesar $93(\mathrm{t}$ hitung > t table), tingkat signifikansi 0,05/2 (uji 2 sisi), dengan tingkat signifikansi sebesar 0,001 lebih kecil dari nilai alpha 0,05 $(0,001<0,05)$. Dapat disimpulkan bahwa 
untuk hipotesis $2 \mathrm{Ha}$ diterima dan Ho ditolak yang berarti bahwa persepsi kemudahan berpengaruh positif dan signifikan terhadap intensitas perilaku dalam penggunaan e filling.

Nilai t hitung variabel kerumitan (X3) adalah sebesar 0,642 yang lebih kecil apabila dibandingkan dengan nilai $\mathrm{t}$ table sebesar 1.985degree of freedom sebesar 93 ( $\mathrm{t}$ hitung $>$ t table), tingkat signifikansi 0,05/2 (uji 2 sisi), dengan tingkat signifikansi sebesar 0,522 lebih besar dari nilai alpha $0,05(0,522>0,05)$. Dapat disimpulkan bahwa untuk hipotesis Ha ditolak dan Ho diterima yang berarti bahwa kerumitan tidak berpengaruhterhadap intensitas perilaku dalam penggunaan e filling.

Nilai t hitung variabel keamanan dan kerahasiaan (X4) adalah sebesar 1,162 yang lebih besar apabila dibandingkan dengan nilai t table sebesar 1,985 degree of freedom sebesar 93 (t hitung > t table), tingkat signifikansi 0,05/2 (uji 2 sisi), dengan tingkat signifikansi sebesar 0,248 lebih besar dari nilai alpha $0,05(0,248<0,05)$. Dapat disimpulkan bahwa untuk hipotesis 4 Ho diterima dan Ha ditolak yang berarti bahwa keamanaan dan kerahasiaantidak berpengaruh terhadap intensitas perilaku dalam penggunaan e filling.

Nilai thitung variabel kesiapan tekhnologi informasi wajib pajak (X5) adalah sebesar 2,357 yang lebih besar apabila dibandingkan dengan nilai t table sebesar 1,985 degree of freedom sebesar 93 ( $\mathrm{t}$ hitung > t table), tingkat signifikansi 0,05/2 (uji 2 sisi), dengan tingkat signifikansi sebesar 0,021 lebih kecil dari nilai alpha 0,05 $(0,021<0,05)$. Dapat disimpulkan bahwa untuk hipotesis $5 \mathrm{Ha}$ diterima dan Ho ditolak yang berarti bahwa kesiapan tekhnologi informasi wajib pajak berpengaruh positif dan signifikan terhadap intensitas perilaku dalam penggunaan e filling.

Nilai thitung variabel penyuluhan kepada wajib pajak (X6) adalah sebesar 2,995 yang lebih besar apabila dibandingkan dengan nilai t table sebesar 1,985 degree of freedom sebesar 93 (t hitung $>\mathrm{t}$ table), tingkat signifikansi 0,05/2 (uji 2 sisi), dengan tingkat signifikansi sebesar 0,004 lebih kecil dari nilai alpha $0,05(0,004<0,05)$. Dapat disimpulkan bahwa untuk hipotesis $6 \mathrm{Ha}$ diterima dan Ho ditolak yang berarti bahwa penyuluhan kepada wajib pajak berpengaruh positif dan signifikan terhadap intensitas perilaku dalam penggunaan $e$-filling.

\section{PEMBAHASAN}

\section{Pengaruh Persepsi Kegunaan Terhadap Intensitas Perilaku Dalam Penggunaan $E$ - Filling}

Berdasarkan hasil uji statistik t pada tabel 11 memperlihatkan bahwa variabel persepsi kegunaan berpengaruh positif dan signifikan terhadap variabel intensitas perilaku dalam penggunaan $e$ filling dengan nilai t hitung sebesar 4,138 lebih besar dari nilai $\mathrm{t}$ table sebesar 1,985 dengan tingkat signifikansi dibawah 0,05. Persepsi kegunaan secara langsung dapat mempengaruhi niat untuk mencoba dan menggunakan sistem $e$-filling. Jika wajib pajak merasakan manfaatnya, ia akan berniat menggunakan sistem $e$-filling, sebaliknya jika wajib pajak tidak merasakan manfaat sistem e-filling, ia tidak akan berniat untuk menggunakannya (Susanto, 2011). Hasil penelitian ini menunjukkan hasil 
yang sama dengan penelitian yang dilakukan oleh Pikkarainen, et al. (2004) yang menyatakan bahwa perceived usefulness berpengaruh positif dan signifikan terhadap behavioral inention.

\section{Pengaruh Persepi Kemudahan Terhadap Intensitas Perilaku Dalam Penggunaan E-Filling}

Berdasarkan hasil uji statistik t pada tabel 11 memperlihatkan bahwa variabel pesepsi kemudahan berpengaruh positif dan signifikan terhadap variabel intensitas perilaku dalam penggunaan $e$-filling dengan nilai t hitung sebesar 3,274 lebih besar dari nilai t table sebesar 1,985 dengan tingkat signifikansi dibawah 0,05. Kemudahan menggunakan didefinisikan sebagai sejauh mana seseorang percaya bahwa menggunakan suatu tekhnologi akan bebas dari usaha (Hartono, 2017 : 114 dalam Salim, 2014). Jadi, seseorang tidak akan merasa terbebani oleh adanya tekhnologi tersebut, karena kemudahan dalam penggunaanya. Hasil penelitian ini konsisten dengan penilitian yang dilakukan oleh Wang, et al. (2003) yang menyatakan bahwa perceived ease of use berpngaruh signifikan positif terhadap compuerself-efficacy. Pikkarain et al (2004) menyatakan bahwa perceived ease of use berpengaruh signifikan positif terhadap penerimaan sistem online banking.

Pengaruh Kerumitan Terhadap Intensitas Perilaku Dalam Penggunaan E-Filling . Berdasarkan hasil uji statistik $\mathrm{t}$ pada tabel 11 memperlihatkan bahwa variabel kerumitan tidak berpengaruh terhadap variabel intensitas perilaku dalam penggunaan $e$ filling dengan nilai t hitung sebesar 0,642lebih kecil dari nilai t table sebesar 1,985 dengan tingkat signifikansi diatas 0,05. Thomson, et al. (1991) dalam Amroso Gardner (2004) menemukan bahwa semakin kompleks (rumit) suatu inovasi, maka akan semakin rendah tingkat penyerapannya. Kerumitan akan muncul, jika wajib pajak belum bisa menerima sebuah tekhnologi baru dalam pelaporan pajaknya (e-filling) dengan alasan belum terbiasa dan mereka menginterprestasikan bahwa tekhnologi yang baru ini dapat menyita waktu dalam mempelajarinya atau bahkan sulit untuk dipahami, sehingga wajib pajak enggan untuk menggunakan $e$-filing. Ketika wajib pajak mempersepsikan bahwa $e$-filling itu rumit, maka mereka cenderung untuk tidak menggunakan e-filling. Hasil penelitian ini tidak sejalan dengan penelitian yang dilakukan oleh Dewi (2009) bahwa kerumitan berpengaruh signifikn positif terhadap minat perilaku penggunaan.

\section{Pengaruh Keamanan Dan Kerahasiaan Terhadap Intensitas Perilaku Dalam Penggunaan E-Filling.}

Berdasarkan hasil uji statistik t pada tabel 11 memperlihatkan bahwa variabel keamanan dan kerahasiaan tidak berpengaruh terhadap variabel intensitas perilaku dalam penggunaan e-filling dengan nilai t hitung sebesar 1,162 lebih kecil dari nilai t tabel sebesar 1,985 dengan tingkat signifikansi dibawah 0,05 .

Suatu sistem informasi dapat dikatakan baik jika keamanan sistem tersebut dapat diandalkan. Kemanan sistem ini dapat dilihat melalui data pengguna yang aman disimpan oleh suatu sistem informasi. Data pengguna ini harus terjaga kerahasiaannya dengan cara data disimpan oleh sistem sehingga pihak lain tidak dapat mengakses data 
pengguna secara bebas. Jika data pengguna dapat disimpan secara aman maka akan memperkecil kesempatan pihak lain untuk menyalahgunakan data pengguna sistem.

Dalam penelitian ini, keamanan dan kerahasiaan tidak berpengaruh terhadap penggunaan fasilitas $e$-filling. Hal ini dikarenakan pihak yang berwenang memberikan jaminan keamanan dan kerahasiaan data.Untuk menjamin keamanan dan kerahasiaan data yang telah disampaikan pihak yang bersangkutan memberikan e-Fin dan digital certificate yang digunakan untuk proteksi data SPT dalam bentuk encryption (pengacakan) sehingga benar-benar terjamin kerahasiaannya. Maka wajib pajak beranggapan bahwa pihak ASP (Application Servive Provder) telah memperhatikan keamanan dan kerahasiaan mereka sehingga wajib pajak tidak terlalu memperhatikan seberapa kuatnya perangkat teknologi untuk keamanan dan kerahasiaan sistem informasi dari e-filling. Hasil peneltian untuk variabel ini tidak sejalan dengan penelitian yang telah dilakukan oleh Desmayanti (2012), Salim (2013) dan penelitian yang dilakukan oleh Wowor (2014) dan Wahyuni (2015) yang menyatakan bahwa keamanan dan kerahasiaan berpengaruh terhadap penggunaan fasilitas $e$-filling.

\section{Pengaruh Kesiapan Tekhnologi Informasi Wajib Pajak Terhadap Intensitas Perilaku Dalam Penggunaan E-Filling.}

Berdasarkan hasil uji statistik t pada memperlihatkan bahwa variabel kesiapan tekhnologi informasi wajib pajak berpengaruh positif dan signifikan terhadap variabel intensitas perilaku dalam penggunaan $e$-filling dengan nilai t hitung sebesar 2,357 lebih besar dari nilai t tabel sebesar 1,985 dengan tingkat signifikansi diatas 0,05. Persepsi kesiapan teknologi mempengaruhi keinginan dalam menggunakan sistem informasi. Kemudian akan timbul minat untuk menggunakan $e$-filing apabila pada dasarnya wajib pajak bersedia menerima sebuah teknologi baru dalampelaporan pajaknya. Jika persepsi kesiapan teknologiitu tinggi maka minatpenggunaan semakin meningkat. Peningkatan minat ini akan mempengaruhi intensi penggunaan sistem informasi secara berkelanjutan.

Kesiapan teknologi pada dasarnya dipengaruhi oleh individu itu sendiri, apakah dari dalam diri individu siap menerima tekhnologi khususnya dalam hal ini e-filling. Jika wajib pajak bisa menerima sebuah tekhnologi baru maka wajib pajak tersebut tidak ragu-ragu untuk melaporkan pajaknya menggunakan e-filling. Hasil penelitian ini konsisten dengan penelitian yang dilakukan oleh Llias, et al. (2009) yang mengungkapkan bahwa hubungan antara tingkat kesiapan tekhnologi dan minat terhadap sistem $e$-filling berpengaruh positif.

\section{Pengaruh Penyuluhan Kepada Wajib Pajak Terhadap Intensitas Perilaku Dalam Penggunaan E-Filling.}

Berdasarkan hasil uji statistik t pada tabel 11 memperlihatkan bahwa variabel penyuluhan kepada wajib pajak berpengaruh positif dan signifikan terhadap variabel intensitas perilaku dalam penggunaan $e$-filling dengan nilai t hitung sebesar 2,995 lebih besar dari nilai t table sebesar 1,985 dengan tingkat signifikansi dibawah 0,05.

Penyuluhan penggunaan e-filing dilingkungan masyarakat sangat efektif karena pentingnya perkenalan tentang $e$-filling merupakan sasaran yang mudah dijangkau, oleh 
sebab itu penggunaan e-filing sangat membantu kemudahan untuk membayar pajak. Salah satu upaya pemberian pemahaman tentang pembayaran pajak melalui $e$-filling dengan cara penyuluhan. Penyuluhan dapat dilkukan dengan berbagai metode dan media yang disesuaikan dengan sasaran.

\section{KESIMPULAN}

Secara simultan terdapat pengaruh positif dan signifikan antara variabel independen persepsi kegunaan (X1), persepsi kemudahan (X2), kerumitan (X3), keamanaan dan kerahasiaan (X4), kesiapan tekhnologi informasi wajib pajak (X5) dan penyuluhan kepada wajib pajak (X6) terhadap intensitas perilaku dalam penggunaan $e$-filling (Y).

Secara parsial, keempat variabel independen yaitu persepsi kegunaan (X1), persepsi kemudahan (X2), kesiapan tekhnologi informasi wajib pajak (X5) dan penyuluhan kepada wajib pajak (X6)berpengaruh terhadap variabel dependen intensitas perilaku dalam penggunaan $e$-filling (Y). Secara parsial variabel independen kerumitan (X3)\& keamanan dan kerahasiaan (X4) tidak berpengaruh terhadap intensitas perilaku dalam penggunan $e$-filling (Y).

$\mathrm{R}$ square menunjukkan bahwa intensitas perilaku dalam penggunan $e$-filling yang ada di Kantor Pelayanan Pajak Pratama Bengkulu dipengaruhi oleh variabel persepsi kegunaan, persepsi kemudahan, kerumitan, keamanaan dan kerahasiaan, kesiapan tekhnologi informasi wajib pajak dan penyuluhan kepada wajib pajak sebesar $67 \%$ dan sisanya 33\% dipengaruhi oleh variabel lain yang belum diteliti dan tidak termasuk dalam analisis regresi ini.

Petugas pajak harus lebih aktif dalam mensosialisasikan kegiatan atau produk-produk terbaru yang akan dirilis dan terus memperbaiki kualitas sistem $e$-filling yang sudah ada.

\section{DAFTAR PUSTAKA}

Arikunto, Suharsimi. 2010. Prosedur Penelitian Suatu Pendekatan Praktek.Edisi Revisi VI.Jakarta: Rineka Cipta.

Duwi Priyatno. 2010. Teknik Mudah Dan Cepat Melakukan Analisis Data Penelitian Dengan SPSS.Yogyakarta : Gava Media.

Dewi, A.A., Ratih, Khomalyana. 2010. Analisis Faktor-Faktor yang mempengaruhi Penerimaan Wajib Pajak terhadap Penggunaan E-Filing. Universitas Diponegoro. Tembalang.

Djoko Muldjono. 2010. Hukum Pajak-Konsep, Aplikasi, dan Penuntun Praktis. Yogyakarta: Andi Yogyakarta.

Ghozali, Imam. 2011. Aplikasi Analisis Multivariate Dengan Program SPSS. Edisi Kelima. Semarang: Badan Penerbit Universitas Diponegoro.

Kementrian Keuangan Republik Indonesia, 2012. Susunan Dalam Satu Naskah UU Perpajakan. Jakarta Selatan : Direktorat Jendral Pajak. 
Lie, Ivana dan Arja Sadjiarto. 2013. Faktor-Faktor Yang Mempengaruhi Minat Perilaku Wajib Pajak Untuk Menggunakan e-Filing. TAX \& ACCOUNTING REVIEW, VOL. 3, NO.2, 2013. Universitas Kristen Petra

Mujiyati, 2010. Faktor-Faktor yang Mempengaruhi penggunaan E-felling Bagi Wajib Pajak Orang Pribadi. Syariah Paper Accounting FEB UMS.

Mardiasmo, 2011. Perpajakan Edisi Revisi 2009. Andi Offset, Yogyakarta.

Pancawati Hardiningsih, 2011. Faktor-faktor Yang Mempengaruhi Kemauan Membayar Pajak. Dinamika Keuangan Dan Perbankan. Vol 3 No 1 Hal 126-142.

Pratama, Agustyan. 2010. Analisis Technology Acceptance Model (TAM) dan Faktorfaktor yang Mempengaruhi Kepuasan Pemakai Sistem Informasi Berbasis Komputer. Universitas Diponegoro

Pikkarainen,T., Pikkarainen, K., Karjaluoto, H., and Pahnila, S. 2011. "Consumer acceptance of online banking: an extension of the technology acceptance model". Internet Research. Vol. 14, No. 3, pp. 224-235.

Rochmat Soemitro (2012). Perpajakan Teori dan Teknis Pemungutan. Bandung: Graha Ilmu.

Siti Kurnia Rahayu, 2010. Perpajakan Indonesia: Konsep \& Aspek Formal. Yogyakarta: Graha Ilmu.

Sugiyono. 2010. Metode Penelitian Bisnis.Bandung : Alfabeta.

Wiyono,Adrianto Sugiarto. 2012. Evaluasi Penerimaan Wajib Pajak terhadap Penggunaan E-Filing sebagai Sarana Pelaporan Pajak secara Online dan Realtime. Jurnal Riset Akuntansi Indonesia, Vol.11,No.2,h.117- 132.Universitas Gajah Mada.Yogyakarta

Widayanti dan Nurlis. 2010. Faktor-Faktor yang Mempengaruhi Kemauan Untuk Membayar Pajak Wajib Pajak Orang Pribadi yang Melakukan Pekerjaan Bebas :Studi kasus pada KPP Pratama Gambir Tiga.Simposium Nasional Akuntansi 13.

Wang, Y-S., Wang, Y-M., Lin, H-H., Tang, T-I. 2010. International Journal of Service Industry Management. Vol. 14, No. 5, pp. 501-519.

Yustinus Prastowo, 2011. Panduan Lengkap Pajak.Jakarta : Raih Asa Sukses. 